\title{
HIGH-EFFICIENCY CERAMIC RECUPERATORS TO GLASS FURNACES
}

\section{Notation:}

$\alpha-$ convection heat-transfer coefficient to air, $\mathrm{W} /\left(\mathrm{m}^{2} \cdot \mathrm{K}\right)$

$\alpha_{g}$ - heat-transfer coefficient of furnace gas, $\mathrm{W} /\left(\mathrm{m}^{2} \cdot \mathrm{K}\right)$

$\mathrm{c}_{a}$ - heat capacity of air, $\mathrm{kJ} /\left(\mathrm{m}^{3} \cdot \mathrm{K}\right)$

$\mathrm{c}_{g}$ - heat capacity of furnace gas, $\mathrm{kJ} /\left(\mathrm{m}^{3} \cdot \mathrm{K}\right)$

$C_{o}-$ constant of radiation, $\mathrm{W} /\left(\mathrm{m}^{2} \cdot \mathrm{K}^{4}\right)$

$D, d$ - diameter, $\mathrm{m}$

$\varepsilon-$ emissivity

$F$ - heating surface area, $\mathrm{m}^{2}$

$\varphi-$ surface area factor

$k$ - over-all heat-transfer coefficient, $\mathrm{W} /\left(\mathrm{m}^{2} \cdot \mathrm{K}\right)$

$\lambda$ - thermal conductivity, $\mathrm{W} /(\mathrm{m} \cdot \mathrm{K})$

$s$ - thickness of wall, $\mathrm{m}$

$\Delta p$ - pressure drop, $\mathrm{Pa}$

$T, t$ - temperature, $\mathrm{K},{ }^{\circ} \mathrm{C}$

$Q$ - heat transfer rate, $\mathrm{kW}$

$V-$ volumetric rate of fluid flow, $\mathrm{m}^{3} / \mathrm{h}, \mathrm{m}^{3} / \mathrm{s}$

$\xi$ - number of heat losses

* Ph.D.; Faculty of Metals Engineering and Industrial Computer Science, AGH University of Science and Technology, Cracow, Poland; dabrowsk@metal.agh.edu.pl 


\section{INTRODUCTION}

Furnace gases coming from glass melting furnaces contain a high amount of thermal energy. In high-efficiency glass melting furnaces there are $50 \%$ of total fuel consumption. The furnace gases are polluted by melted glass components. Temperatures of furnaces gas come up to $1200^{\circ} \mathrm{C} \div 1500^{\circ} \mathrm{C}$. For heat recovery of waste gas flow from glass melting furnaces metal recuperators, ceramic recuperators and regenerators [2,3] are used. Preheating in exchangers air is used directly in combustion of fuel. Thermal efficiency and service life of heat exchangers are major importance of optimization for this furnaces.

Achieving the energy saving is determined by the heat recovery system. New heat exchangers to glass melting furnaces are from $15 \%$ to $25 \%$ more efficient than of the conventional heat exchangers used in furnaces some years ago.

Hot air temperatures can be achieved:

- in metal recuperator up to $600 \div 800^{\circ} \mathrm{C}[3,4]$,

- in conventional ceramic up to $900^{\circ} \mathrm{C}[6]$,

- in high efficiency ceramic up to $1250^{\circ} \mathrm{C}$ [7].

The conventional ceramic recuperators comprise the following designs: Lambot [6] Hermansen [6], Chapman - Stein [5] made of chamotte, sillimanite or carborundum shapes. Improvement the recuperator's designs with higher air temperature, higher thermal efficiency, smaller weight and smaller over-all dimensions makes possible manufacture of new generation of fusion cast alumina-mullite-zirconia materials [7] and izostaticly pressed magnesia materials [7].

\section{NEW GENERATION OF MATERIALS TO CERAMIC RECUPERATORS}

ZM Ropczyce for many years has specialized in the manufacture of basic refractory materials, including the ones for the glass-making industry.

In 2002 izostaticly pressed magnesia shapes Glasmag M98G was developed and implemented. This materials to ceramic recuperators for glass melting furnaces are used. Magnesia shapes have the following major parameters:

- chemical analysis: $\mathrm{MgO}-98 \%, \mathrm{Al}_{2} \mathrm{O}_{3}-0.1 \%, \mathrm{Fe}_{2} \mathrm{O}_{3}-0.3 \%, \mathrm{CaO}-0.8 \%, \mathrm{SiO}_{2}-0.2 \%$;

- open porosity: $15.4 \%$;

- bulk density: $2.97 \mathrm{~g} / \mathrm{cm}^{3}$;

- cold crushing strength: $58 \mathrm{MPa}$;

- refractoriness under load: $T_{0.6}>1700^{\circ} \mathrm{C}$.

Similar class of materials used to ceramic recuperators are fusion cast alumina-mullitezirconia shapes.

The cast shapes have the following major parameters:

- chemical analysis: $\mathrm{Al}_{2} \mathrm{O}_{3}-50 \%, \mathrm{ZrO}_{2}-33 \%, \mathrm{SiO}_{2}-14 \% \ldots$;

- open porosity: $2 \%$;

- bulk density: $3.3 \mathrm{~g} / \mathrm{cm}^{3}$;

- cold crushing strength: $350 \mathrm{MPa}$;

- refractoriness under load: $T_{0.6}>1700^{\circ} \mathrm{C}$. 
New generation of shapes has the following quality:

- high density,

- dimensional accuracy,

- thermal conductivity are multiples of those of conventional refractories,

- no decrease on account of corrosion,

- no shinhage or expansion,

- no phase changes,

- high mechanical strength,

- less sensitive to thermal stresses.

The function thermal conductivity temperature $[4,7]$ for shapes are given in Table 1.

Table 1. The function thermal conductivity temperature for shapes

\begin{tabular}{|c|c|c|c||}
\hline $\begin{array}{c}\text { Temperature } \\
{ }^{\circ} \mathrm{C}\end{array}$ & $\begin{array}{c}\text { Alumina-mullite- } \\
\text { zircona shapes } \\
\mathrm{W} /(\mathrm{m} \cdot \mathrm{K})\end{array}$ & $\begin{array}{c}\text { Magnesia shapes } \\
\mathrm{W} /(\mathrm{m} \cdot \mathrm{K})\end{array}$ & $\begin{array}{c}\text { Chamotte shapes } \\
\mathrm{W} /(\mathrm{m} \cdot \mathrm{K})\end{array}$ \\
\hline 400 & 5.0 & 4.5 & 1.2 \\
\hline 600 & 4.1 & 3.9 & 1.3 \\
\hline 800 & 4.0 & 3.5 & 1.4 \\
\hline 1000 & 4.2 & 3.2 & 1.5 \\
\hline 1200 & 5.1 & 3.0 & 1.6 \\
\hline 1400 & 6.0 & - & - \\
\hline
\end{tabular}

The advantage of fusion cast heat exchangers shapes is that they may be combined with conventional burning refractories. It makes possible to install the fusion cast elements only in the most severally stressed areas. For example: in top layers of conventional ceramic recuperator checkers or before the metal recuperator to avoid burning through. These areas are exposed to flue gases and dust. For temperature ranges in glass melting furnaces do not evaporated melted glass components: silica, compound of aluminum, calcium and magnesium. The alcalies have the high volatilaty. Fusion cast shapes will practically do not decrease on account corrosion. Magnesia shapes will not react with alcalies. On account of material costs the ceramic recuperator should be calculated by mathematical model to achieve required construction and service characteristic for minimal number of shapes.

\section{MATHEMATICAL MODEL OF HIGH-EFFICIENCY CERAMIC RECUPERATOR}

To calculate the heat of ceramic recuperators universal balance method is used. Additionally, the mathematical model has to be taken into account: untight furnace gas side, untight air side, heating surface area ratio and thermal resistance of the shape wall.

Ceramic recuperators work in different arrangement of cross-flow air and furnace gas. Typical arrangements of fluid flow in ceramic recuperators illustrates Figure 1. 
The heat calculates are separate for upper and lower row of recuperator checkers. The volumetric rate of air inlet to recuperator is given by equations:

$$
V_{a}^{\prime}=\frac{V_{a}}{1-n}, \quad \Delta V_{a}=V_{a}^{\prime}-V_{a}
$$

where:

$n$ - number of air untight,

$\Delta V_{a}-$ absolute air losses.

a)

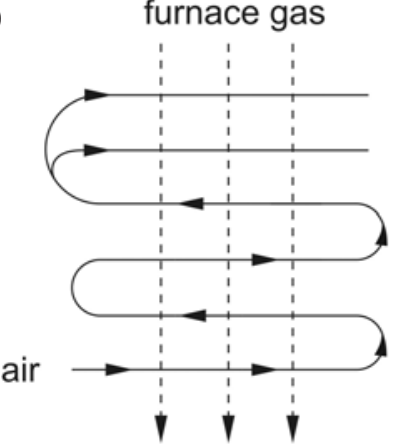

b)

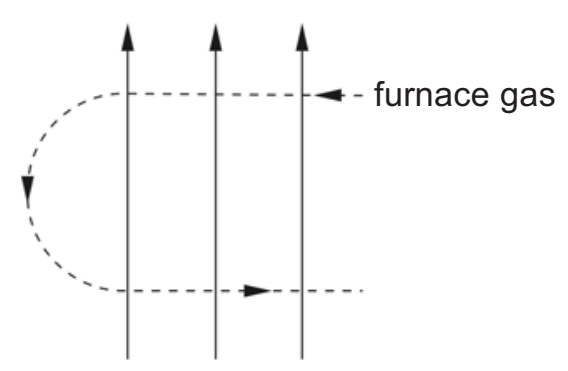

Fig. 1. Typical arrangement of fluid flow in ceramic recuperators: a) air cross-flow; b) furnace gas cross-flow

The volumetric rate of furnace gas outlet recuperator is

$$
V_{g}^{\prime \prime}=V_{g}^{\prime}+\Delta V_{a}
$$

The heat transfer rate of recuperator equals

$$
Q_{a}=\frac{V_{a}^{\prime}+V_{a}}{2} c_{a}\left(t_{a}^{\prime}-t_{a}\right)
$$

where:

$V_{a}^{\prime}$ - volumetric rate of air with untight taken into account,

$V_{a}-$ volumetric rate of air,

$c_{a}-$ heat capacity of air,

$t_{a}^{\prime}-$ outlet air temperature,

$t_{a}-$ inlet air temperature. 
The heat transfer rate of furnace gas inlet to recuperator is

$$
Q_{g}^{\prime}=\xi V_{g}^{\prime} c_{g}^{\prime} t_{g}^{\prime}
$$

where:

$\xi$ - number of heat losses,

$V_{g}^{\prime}$ - volumetric rate of furnace gas inlet to recuperator,

$c_{g}^{\prime}-$ heat capacity of furnace gas,

$t_{g}^{\prime} \quad-$ inlet furnace gas temperature.

The outlet furnace gas temperature is given by formula

$t_{g}^{\prime \prime}=\frac{\xi Q_{a}^{\prime}-Q_{a}}{V_{g}^{\prime \prime} c_{g}^{\prime \prime}}$

where $c_{g}^{\prime \prime}$ - inlet heat capacity of furnace gas.

The logarithmic mean temperature equals

$$
\Delta t_{m}=\frac{\Delta t^{\prime}-\Delta t^{\prime \prime}}{\ln \frac{\Delta t^{\prime}}{\Delta t^{\prime \prime}}}
$$

The calculations of over-all heat coefficient are performed to upper row and lower row of recuperator checkers.

The convection heat transfer coefficient to air is given by equation to counter-flow across inline banks of tubes [4]

$$
\alpha=\left(5.04+0.00382 t_{a}\right) \frac{w_{a}^{0.65}}{D^{0.35}}
$$

where:

$t_{a}-$ inlet or outlet air temperature,

$w_{a}$ - velocity of air,

$D$ - outer diameter of tube.

The heat-transfer coefficient of furnace gas is given by equation to flow inside tube [4]

$$
\alpha_{g}=\left(3.51+0.00311 t_{g}\right) \frac{w_{g}^{0.8}}{d^{0.2}}
$$

where:

$t_{g}$ - inlet or outlet furnace gas temperature,

$w_{g}$ - velocity of furnace gas,

$d$ - diameter of tube. 
The emissivity of furnace gas $[4,6]$ is described by equation

$$
\varepsilon_{g}=\beta_{\mathrm{CO}_{2}} \varepsilon_{\mathrm{CO}_{2}}+\beta_{\mathrm{H}_{2} \mathrm{O}} \varepsilon_{\mathrm{H}_{2} \mathrm{O}}-\Delta \varepsilon_{g}
$$

where:

$$
\begin{aligned}
& \varepsilon_{\mathrm{CO}_{2}} \text { - emissivity of carbon dioxide, } \\
& \varepsilon_{\mathrm{H}_{2} \mathrm{O}} \text { - emissivity of water wapour, }
\end{aligned}
$$

$\beta_{\mathrm{CO}_{2}}, \beta_{\mathrm{H}_{2} \mathrm{O}}, \Delta \varepsilon_{g}-$ correction factors.

The effective emissivity of wall is [4]

$$
\varepsilon_{w}^{\prime}=\frac{\varepsilon_{w}+1}{2}
$$

The radiation heat-transfer coefficient of furnace gas is given by system of equations

$$
\left\{\begin{array}{l}
\alpha_{r}=\frac{\varepsilon_{g} \varepsilon_{w}^{\prime} C_{o}\left[\left(\frac{T_{g}}{100}\right)^{4}-\left(\frac{T_{w}}{100}\right)^{4}\right]}{T_{g}-T_{w}} \\
T_{w}=T_{a}+\frac{k}{\alpha}\left(T_{g}-T_{a}\right)
\end{array}\right\}
$$

where:

$C_{o}-$ constant of radiation,

$T_{g}$ - furnace gas temperature,

$T_{w}$ - wall temperature,

$T_{a}$ - air temperature.

The heat-transfer coefficient of furnace gas is

$\alpha_{g}=\alpha_{r}+\alpha_{c}$

The ratio $s / \lambda$ is the thermal resistance of the tube wall.

The surface area factor is [1]

$$
\varphi=\frac{F_{a_{1}}}{F_{g_{1}}}
$$

where:

$F_{a_{1}}$ - heat surface area of shape to air side,

$F_{g_{1}}$ - heat surface area of shape to furnace gas side. 
The over-all heat-transfer coefficient to inlet or outlet of recuperator equals

$$
k=\frac{1}{\frac{\varphi}{\alpha_{g}}+\frac{\varphi s}{\lambda}+\frac{1}{\alpha}}
$$

The mean heat-transfer coefficient is

$$
\bar{k}=\frac{k^{\prime}+k^{\prime \prime}}{2}
$$

The heat surface area of recuperator is given by equation

$$
F=\frac{Q_{a}}{\bar{k} \Delta t_{m}}
$$

The number of shapes in recuperator is

$$
N=\frac{F}{F_{a_{1}}}
$$

The number of rows in height of recuperator is given by equation

$$
Z=\frac{N}{\{x \cdot y\}}
$$

where $\{x \cdot y\}-$ arrangement of tubes in recuperator layer.

Mathematical model is applied to calculations of the ceramic recuperator made of magnesia shapes.

\section{THE CALCULATION OF CERAMIC RECUPERATOR TO GLASS TANK}

The ceramic recuperator uses a heat of waste gas from glass tank. Preheating in recuperator air is used directly in combustion of fuel.

The recuperator works in cross-flow (Fig. 1a) and has the following parameters:

- volumetric rate of air $V_{a}=1000 \mathrm{~m}^{3} / \mathrm{h}\left(0.278 \mathrm{~m}^{3} / \mathrm{s}\right)$,

- inlet air temperature

$t_{a}=20^{\circ} \mathrm{C}$,

- outlet air temperature $t_{a}^{\prime}=600^{\circ} \mathrm{C}$,

- volumetric rate of furnace gas inlet to recuperator $V_{g}^{\prime}=1200 \mathrm{~m}^{3} / \mathrm{h}\left(0.33 \mathrm{~m}^{3} / \mathrm{s}\right)$,

- inlet furnace gas temperature to recuperator $t_{g}^{\prime}=1300^{\circ} \mathrm{C}$,

- chemical composition of furnace gas $\mathrm{CO}_{2}-10 \%, \mathrm{H}_{2} \mathrm{O}-18 \%$,

- number of heat losses $\xi=0.95$. 
The recuperator made of magnesia shapes by Figure 2, with the following dimensions:

- outer diameter of tube

- inner diameter of tube

- thickness of tube wall

- total height

- height of heat element

- pitch of shapes

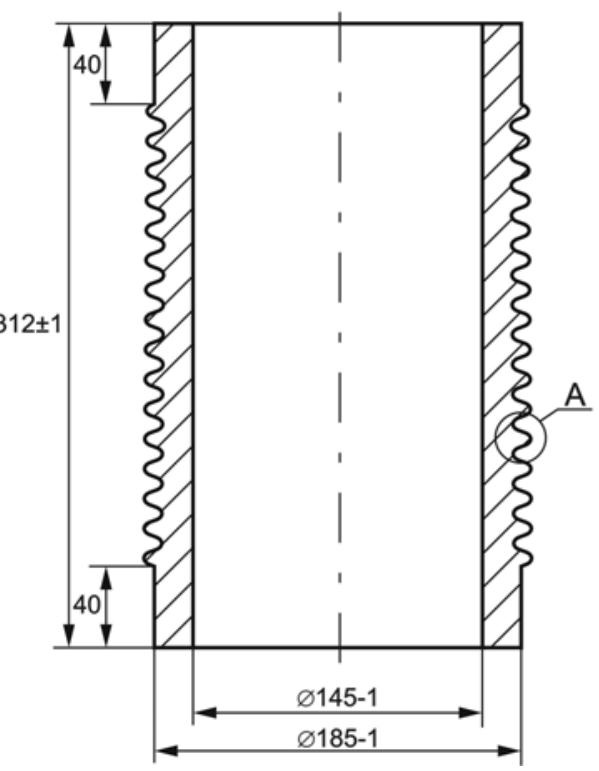

Fig. 2. Magnesia M98G recuperator shape
$D=0.187 \mathrm{~m}$,

$d=0.145 \mathrm{~m}$,

$s=0.021 \mathrm{~m}$,

$h=0.312 \mathrm{~m}$,

$h_{1}=0.232 \mathrm{~m}$,

$p=0.11 \mathrm{~m}$.

A $(2: 1)$

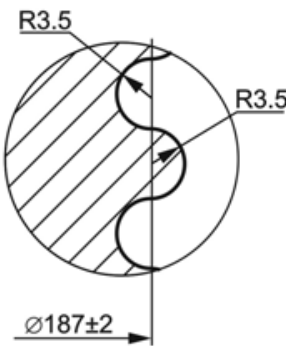

The volumetric rate of air inlet to recuperator is

$V_{a}^{\prime}=\frac{V_{a}}{1-n}=\frac{1000}{1-0.15}=1176 \mathrm{~m}^{3} / \mathrm{h}=0.327 \mathrm{~m}^{3} / \mathrm{s}$,

- untight of air channel $n=15 \%$.

The absolute untight of air equals

$\Delta V_{a}=V_{a}^{\prime}-V_{a}=1176-1000=176 \mathrm{~m}^{3} / \mathrm{h}$. 
The volumetric rate of furnace gas outlet from recuperator is

$V_{g}^{\prime \prime}=1200+176=1376 \mathrm{~m}^{3} / \mathrm{h}=0.382 \mathrm{~m}^{3} / \mathrm{s}$.

Substituting the values into equation (3) we obtain heat transfer rate of recuperator

$Q_{a}=\frac{V_{a}+V_{a}^{\prime}}{2} c_{a}\left(t_{a}^{\prime \prime}-t_{a}\right)=\frac{0.278+0.327}{2} \cdot 1.34(600-20)=235.1 \mathrm{~kW}$.

The heat transfer rate of furnace gas inlet to recuperator is

$Q_{g}^{\prime}=V_{g}^{\prime} c_{g}^{\prime} \cdot t_{g}^{\prime}=0.33 \cdot 1.65 \cdot 1300=707.9 \mathrm{~kW}$

Substituting the values into equation (5) we obtain outlet furnace gas temperature

$t_{g}^{\prime \prime}=\frac{\xi Q_{g}^{\prime}-Q_{a}}{V_{g}^{\prime \prime} c_{g}^{\prime \prime}}=\frac{0.95 \cdot 707.9-235.1}{0.383 \cdot 1.5}=761^{\circ} \mathrm{C}$.

The logarithmic mean temperature equals

$\Delta t_{m}=\frac{\Delta t^{\prime \prime}-\Delta t^{\prime}}{\ln \frac{\Delta t^{\prime \prime}}{\Delta t^{\prime}}}=\frac{741-700}{\ln \frac{741}{700}}=721 \mathrm{~K}$,

- inlet $\Delta t^{\prime}=1300-600=700^{\circ} \mathrm{C}$,

- outlet $\Delta t^{\prime \prime}=761-20=741^{\circ} \mathrm{C}$.

The recuperator row of shapes in layer is

$\{x \cdot y\}=\{8 \cdot 7\}$

The calculations of over-all heat-transfer coefficient - upper row

The convection heat-transfer coefficient to air is

$\alpha=\left(5.04+0.00382 t_{a}^{\prime}\right) \frac{w_{a}^{0.65}}{D^{0.35}}=(5.04+0.00382 \cdot 600) \frac{0.78^{0.65}}{0.187^{0.35}}=11.1 \mathrm{~W} /\left(\mathrm{m}^{2} \cdot \mathrm{K}\right)$,

where:

$t_{a}^{\prime}-$ air temperature, $t_{a}^{\prime}=600^{\circ} \mathrm{C}$,

$w_{a}$ - velocity of air 


$$
w_{a}=\frac{V_{a}}{f_{a}}=\frac{V_{a}}{2 \cdot 7 \cdot p h_{1}}=\frac{0.278}{14 \cdot 0.11 \cdot 0.232}=0.78 \mathrm{~m} / \mathrm{s}
$$

$D$ - outer diameter of tube, $D=0.187 \mathrm{~m}$.

The convection heat-transfer coefficient of furnace gas equals

$$
\alpha_{c}=\left(3.51+0.00311 t_{g}^{\prime}\right) \frac{w_{g}^{0.8}}{d^{0.2}}=(3.51+0.00311 \cdot 1300) \frac{0.36^{0.8}}{0.145^{0.2}}=4.9 \mathrm{~W} /\left(\mathrm{m}^{2} \cdot \mathrm{K}\right)
$$

where:

$t_{g}^{\prime}-$ temperature of furnace gas $t_{g}^{\prime}=1300^{\circ} \mathrm{C}$,

$w_{g}-$ velocity of furnace gas

$$
w_{g}=\frac{V_{g}^{\prime}}{f_{g}}=\frac{V_{g}^{\prime}}{56 \frac{\Pi d_{i}^{2}}{4}}=\frac{0.33}{56 \frac{\Pi \cdot 0.145^{2}}{4}}=0.36 \mathrm{~m} / \mathrm{s},
$$

$d_{i}$ - diameter of tube $d_{i}=0.145 \mathrm{~m}$.

The emissivity of furnace gas by formula (9) is:

$-\mathrm{CO}_{2}$ per cent in furnace gas $-10 \%$;

- $\mathrm{H}_{2} \mathrm{O}$ per cent in furnace gas $-18 \%$;

- layer thickness $s=0.9 d_{i}=0.9 \cdot 0.145=0.13$;

- emissivity of carbon dioxide: $(p \cdot s)_{\mathrm{CO}_{2}}=0.10 \cdot 0.13 \cdot 98.1=1.3 \mathrm{~Pa} \cdot \mathrm{m}$

$t_{g}^{\prime}=1300^{\circ} \mathrm{C}, \varepsilon_{\mathrm{CO}_{2}}=0.04$,

- emissivity of water vapour: $(p \cdot s)_{\mathrm{H}_{2} \mathrm{O}}=0.18 \cdot 0.13 \cdot 98.1=2.3 \mathrm{~Pa} \cdot \mathrm{m}$

$t_{g}=1300^{\circ} \mathrm{C}, \varepsilon_{\mathrm{H}_{2} \mathrm{O}}=0.025$,

- correction factors: $\beta_{\mathrm{CO}_{2}}=1.0, \beta_{\mathrm{H}_{2} \mathrm{O}}=1.05, \Delta \varepsilon_{g}=0$,

$$
\varepsilon_{g}=\beta_{\mathrm{CO}_{2}} \varepsilon_{\mathrm{CO}_{2}}+\beta_{\mathrm{H}_{2} \mathrm{O}} \varepsilon_{\mathrm{H}_{2} \mathrm{O}}-\Delta \varepsilon_{g}=0.04+1.05 \cdot 0.025=0.066 ;
$$


The effective emissivity of wall is

$\varepsilon_{w}^{\prime}=\frac{0.8+1}{2}=0.9$

The radiation factor is

$\varepsilon_{g} \cdot \varepsilon_{w}^{\prime} \cdot C_{o}=0.066 \cdot 0.9 \cdot 5.67=0.34 \mathrm{~W} /\left(\mathrm{m}^{2} \cdot \mathrm{K}^{4}\right)$.

The radiation heat-transfer coefficient of furnace gas is given by system of equations:

$$
\begin{aligned}
& \left\{\begin{array}{c}
\alpha_{r}=\frac{\varepsilon_{g} \varepsilon_{w}^{\prime} C_{o}\left[\left(\frac{T_{g}^{\prime}}{100}\right)^{4}-\left(\frac{T_{w}^{\prime}}{100}\right)^{4}\right]}{T_{g}^{\prime}-T_{w}^{\prime}} \\
T_{w}^{\prime}=T_{a}^{\prime}+\frac{k}{\alpha}\left(T_{g}^{\prime}-T_{a}^{\prime}\right)
\end{array}\right\}, \\
& T_{w}^{\prime}=873+\frac{8.0}{11.1}(1573-873)=1378 \mathrm{~K},
\end{aligned}
$$

where:

$T_{g}^{\prime}$ - furnace gas temperature, $T_{g}^{\prime}=1573 \mathrm{~K}\left(1300^{\circ} \mathrm{C}\right)$,

$T_{a}^{\prime}$ - air temperature, $T_{a}^{\prime}=873 \mathrm{~K}\left(600^{\circ} \mathrm{C}\right)$,

$T_{w}^{\prime}$ - wall temperature, $T_{w}^{\prime}=1378 \mathrm{~K}\left(1105^{\circ} \mathrm{C}\right)$,

$\alpha_{r}=\frac{0.34\left(15.73^{4}-13.78^{4}\right)}{1573-1378}=43.9 \mathrm{~W} /\left(\mathrm{m}^{2} \cdot \mathrm{K}\right)$.

The heat-transfer coefficient of furnace gas is

$\alpha_{g}=\alpha_{c}+\alpha_{r}=4.9+43.9=48.8 \mathrm{~W} /\left(\mathrm{m}^{2} \cdot \mathrm{K}\right)$.

The thermal resistance of the tube wall equals

$$
\frac{s}{\lambda}=\frac{0.021}{3.1}=0.007\left(\mathrm{~m}^{2} \cdot \mathrm{K}\right) / \mathrm{W}
$$


where:

thickness of the wall $s=0.021 \mathrm{~m}$,

thermal conductivity of magnesia shapes $\lambda_{1088}=3.1 \mathrm{~W} /(\mathrm{m} \cdot \mathrm{K})$.

The heat surface area of shape is:

- air side

$F_{a_{1}}=\pi d_{n} h_{1}=\pi \cdot 0.187 \cdot 0.232=0.136 \mathrm{~m}^{2}$

- furnace gas side

$F_{g_{1}}=\pi d_{i} h_{1}=\pi \cdot 0.145 \cdot 0.232=0.106 \mathrm{~m}^{2} ;$

- surface area factor

$\varphi=\frac{F_{a_{1}}}{F_{g_{1}}}=\frac{0.136}{0.106}=1.28$.

The over-all heat-transfer coefficient is

$k^{\prime}=\frac{1}{\frac{\varphi}{\alpha_{g}}+\frac{\varphi \cdot s}{\lambda}+\frac{1}{\alpha}}=\frac{1}{\frac{1.28}{48.8}+1.28 \cdot 0.007+\frac{1}{11.1}}=8.0 \mathrm{~W} /\left(\mathrm{m}^{2} \cdot \mathrm{K}\right)$.

The calculations of over-all heat-transfer coefficient - lower row

The convection heat-transfer coefficient to air is

$\alpha=\left(5.04+0.00382 t_{a}\right) \frac{w_{a}^{0.65}}{D^{0.35}}=(5.04+0.00382 \cdot 20) \frac{1.8^{0.65}}{0.187^{0.35}}=13.4 \mathrm{~W} /\left(\mathrm{m}^{2} \cdot \mathrm{K}\right)$,

where:

$t_{a}$ - air temperature, $t_{a}=20^{\circ} \mathrm{C}$,

$w_{a}-$ velocity of air

$$
w_{a}=\frac{V_{a}^{\prime}}{f_{a}}=\frac{V_{a}^{\prime}}{7 \cdot p h_{1}}=\frac{0.327}{7 \cdot 0.11 \cdot 0.232}=1.8 \mathrm{~m} / \mathrm{s}
$$

$D$ - hydraulic diameter $D=0.187 \mathrm{~m}$.

The convection heat-transfer coefficient of furnace gas is

$$
\alpha_{c}=\left(3.51+0.00311 t_{g}^{\prime \prime}\right) \frac{w_{g}^{0.8}}{d^{0.2}}=(3.51+0.00311 \cdot 761) \frac{0.42^{0.8}}{0.145^{0.2}}=4.3 \mathrm{~W} /\left(\mathrm{m}^{2} \cdot \mathrm{K}\right)
$$


where:

$t_{g}^{\prime \prime}$ - furnace gas temperature, $t_{g}^{\prime \prime}=761^{\circ} \mathrm{C}$,

$w_{g}-$ velocity of furnace gas

$$
w_{g}=\frac{V_{g}^{\prime \prime}}{f_{g}}=\frac{V_{g}^{\prime \prime}}{\frac{56 \pi d_{i}^{2}}{4}}=\frac{0.382}{\frac{56 \cdot \pi \cdot 0.145^{2}}{4}}=0.42 \mathrm{~m} / \mathrm{s}
$$

$d_{i}$ - diameter of tube $d_{i}=0.145 \mathrm{~m}$.

The emissivity of furnace gas to formula (9) equals:

- emissivity of carbon dioxide:

$$
(p \cdot s)_{\mathrm{CO}_{2}}=1.3 \mathrm{~Pa} \cdot \mathrm{m}, t_{g}^{\prime \prime}=761^{\circ} \mathrm{C}, \varepsilon_{\mathrm{CO}_{2}}=0.05 ;
$$

- emissivity of water vapour:

$(p \cdot s)_{\mathrm{H}_{2} \mathrm{O}}=2.3 \mathrm{~Pa} \cdot \mathrm{m}, t_{g}^{\prime \prime}=761^{\circ} \mathrm{C}, \varepsilon_{\mathrm{H}_{2} \mathrm{O}}=0.04$;

- correction factors:

$\beta_{\mathrm{CO}_{2}}=1.0, \beta_{\mathrm{H}_{2} \mathrm{O}}=1.05, \Delta \varepsilon_{g}=0$;

$\varepsilon_{g}=\beta_{\mathrm{CO}_{2}} \varepsilon_{\mathrm{CO}_{2}}+\beta_{\mathrm{H}_{2} \mathrm{O}} \varepsilon_{\mathrm{H}_{2} \mathrm{O}}-\Delta \varepsilon_{g}=0.05+1.05 \times 0.04=0.092$.

The effective emissivity of wall is

$\varepsilon_{w}^{\prime}=\frac{0.8+1}{2}=0.9$.

The radiation factor is

$\varepsilon_{g} \cdot \varepsilon_{w}^{\prime} \cdot C_{o}=0.092 \cdot 0.9 \cdot 5.67=0.47 \mathrm{~W} /\left(\mathrm{m}^{2} \cdot \mathrm{K}^{4}\right)$.

The radiation heat-transfer coefficient of furnace gas is:

$$
\begin{aligned}
& \left\{\begin{array}{l}
\alpha_{r} \varepsilon_{w}^{\prime} C_{o}\left[\left(\frac{T_{g}^{\prime \prime}}{100}\right)^{4}-\left(\frac{T_{w}^{\prime \prime}}{100}\right)^{4}\right] \\
T_{g}^{\prime \prime}-T_{w}^{\prime \prime} \\
T_{w}^{\prime \prime}=T_{a}+\frac{k}{\alpha}\left(T_{g}^{\prime \prime}-T_{a}\right)
\end{array}\right\}, \\
& T_{w}^{\prime \prime}=293+\frac{6.3}{13.4}(1034-293)=641 \mathrm{~K},
\end{aligned}
$$


where:

$T_{g}^{\prime \prime}$ - furnace gas temperature, $T_{g}^{\prime \prime}=1034 \mathrm{~K}\left(761^{\circ} \mathrm{C}\right)$,

$T_{a}$ - air temperature, $T_{a}=293 \mathrm{~K}\left(20^{\circ} \mathrm{C}\right)$,

$T_{w}^{\prime \prime}$ - wall temperature, $T_{w}^{\prime \prime}=641 \mathrm{~K}\left(369^{\circ} \mathrm{C}\right)$,

$\alpha_{r}=\frac{0.47\left(10.34^{4}-6.41^{4}\right)}{1034-641}=11.7 \mathrm{~W} /\left(\mathrm{m}^{2} \cdot \mathrm{K}\right)$.

The heat-transfer coefficient of furnace gas is

$\alpha_{g}=\alpha_{c}+\alpha_{r}=4.3+11.7=16 \mathrm{~W} /\left(\mathrm{m}^{2} \cdot \mathrm{K}\right)$.

The thermal resistance of the tube wall equals

$\frac{s}{\lambda}=\frac{0.021}{4.6}=0.005\left(\mathrm{~m}^{2} \cdot \mathrm{K}\right) / \mathrm{W}$,

where thermal conductivity of magnesia shape $\lambda_{343}=4.6 \mathrm{~W} /(\mathrm{m} \cdot \mathrm{K})$.

The over-all heat-transfer coefficient is

$$
k^{\prime \prime}=\frac{1}{\frac{\varphi}{\alpha_{g}}+\frac{\varphi s}{\lambda}+\frac{1}{\alpha}}=\frac{1}{\frac{1.28}{16}+1.28 \cdot 0.005+\frac{1}{13.4}}=6.3 \mathrm{~W} /\left(\mathrm{m}^{2} \cdot \mathrm{K}\right) .
$$

The mean heat-transfer coefficient is

$\bar{k}=\frac{k^{\prime}+k^{\prime \prime}}{2}=\frac{8.0+6.3}{2}=7.2 \mathrm{~W} /\left(\mathrm{m}^{2} \cdot \mathrm{K}\right)$.

The heat surface area of recuperator is given by equation (16)

$F=\frac{Q_{a}}{\bar{k} \Delta t_{m}}=\frac{235100}{7.2 \cdot 721}=45.3 \mathrm{~m}^{2}$. 
The number of shapes in recuperator equals

$N=\frac{F}{F_{a_{1}}}=\frac{43.5}{0.136}=333$, admited 336

The number of rows on height of recuperator is given by equation (18)

$$
Z=\frac{336}{56}=6
$$

The heat exanger chamber over-all dimensions are the following:

- length $-8 \cdot 0.187+8 \cdot 0.11=2.4 \mathrm{~m}$,

- width $-7 \cdot 0.187+7 \cdot 0.11=2.1 \mathrm{~m}$

- height $-6 \cdot 0.312+0.52=2.4 \mathrm{~m}$.

The heat and geometric parameters of recuperator are given in Table 2. The ceramic recuperator to glass tank using Glasmag M98G materials illustrates Figure 3.

Table 2. Parameters of ceramic recuperator

\begin{tabular}{|c|c|c|}
\hline Parameter & Upper row & Lower row \\
\hline Furnace gas temperature, ${ }^{\circ} \mathrm{C}$ & 1300 & 763 \\
\hline Air temperature, ${ }^{\circ} \mathrm{C}$ & 600 & 20 \\
\hline Volumetric rate of furnace gas, $\mathrm{m}^{3} / \mathrm{h}$ & 1200 & 1376 \\
\hline Volumetric rate of air, $\mathrm{m}^{3} / \mathrm{h}$ & 1000 & 1176 \\
\hline Velocity of furnace gas, $\mathrm{m} / \mathrm{s}$ & 0.36 & 0.42 \\
\hline Velocity of air, m/s & 0.77 & 1.8 \\
\hline Convection heat-transfer coefficient to air, $\mathrm{W} /\left(\mathrm{m}^{2} \cdot \mathrm{K}\right)$ & 11.1 & 13.4 \\
\hline Heat-transfer coefficient of furnace gas, $\mathrm{W} /\left(\mathrm{m}^{2} \cdot \mathrm{K}\right)$ & 48.8 & 16.0 \\
\hline Thermal resistance, $\mathrm{m}^{2} \mathrm{~K} / \mathrm{W}$ & 0.007 & 0.005 \\
\hline Over-all heat-transfer coefficient, $\mathrm{W} /\left(\mathrm{m}^{2} \cdot \mathrm{K}\right)$ & 8.0 & 6.3 \\
\hline Wall temperature, ${ }^{\circ} \mathrm{C}$ & 1105 & 369 \\
\hline Heat transfer rate, $\mathrm{kW}$ & \multicolumn{2}{|c|}{235.1} \\
\hline Logarithmic mean temperature, $\mathrm{K}$ & \multicolumn{2}{|c|}{721} \\
\hline Mean heat-transfer coefficient, $\mathrm{W} /\left(\mathrm{m}^{2} \cdot \mathrm{K}\right)$ & \multicolumn{2}{|c|}{7.2} \\
\hline Surface heat area, $\mathrm{m}^{2}$ & \multicolumn{2}{|c|}{45.3} \\
\hline Recuperator checkers & \multicolumn{2}{|c|}{$8 \cdot 7 \cdot 6$} \\
\hline Number shapes & \multicolumn{2}{|c|}{336} \\
\hline
\end{tabular}




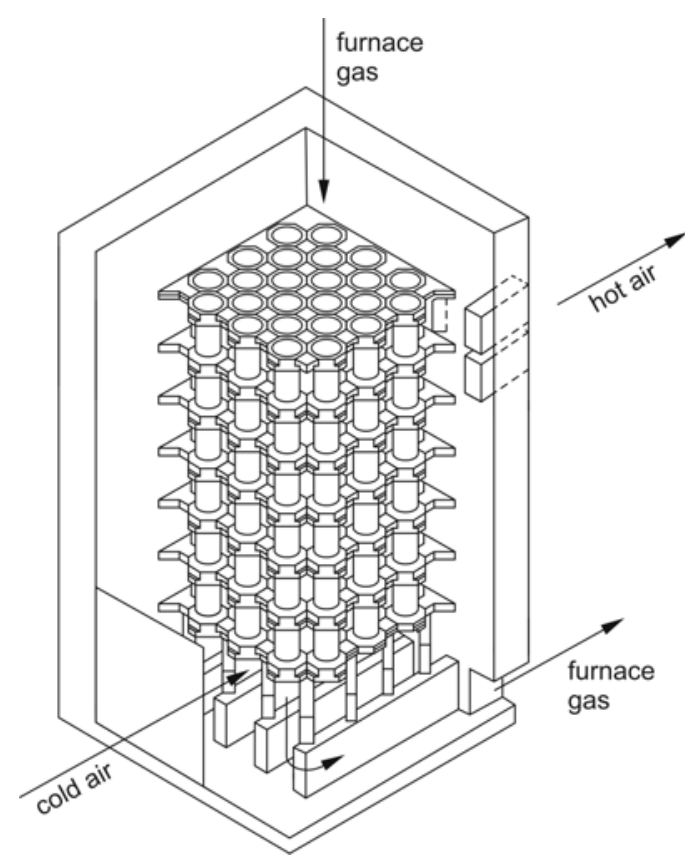

Fig. 3. Ceramic recuperator to tank furnace

\section{INFERENCES}

- Ceramic recuperators using energy of flue gases from glass melting furnaces on account of high-temperature, dust, and thermal shocks work in very difficult conditions.

- The service life of glass melting furnaces is determined by failure-free operation and the effectiveness of recuperators.

- Mathematical model of high-efficiency ceramic recuperator using new generation of shapes makes possible to define recuperator's design and service characteristics: overall dimensions, heat surface area, recuperator checkers, heat transfer ratio, temperatures of fluids and walls.

- The heat exchangers using Glassmag M98G shapes need to be made entirely of magnesia materials. The advantage of cast shapes heat exchangers is that they may be combined with chamotte or sillimanite materials. It makes possible to install cast materials only in the most severally stressed areas.

- High efficiency ceramic recuperators using magnesia materials or casted alumina-mullite-zirconia materials are from 15 to $25 \%$ more thermal efficient than of conventional ceramic heat exchangers.

- In glass melting furnaces the heat exchangers are capable to provide to the user a reduction of total fuel consumption about $15 \div 25 \%$. 


\section{REFERENCES}

[1] Hobler T.: Ruch ciepła i wymienniki. WNT, Warszawa, 1979

[2] Karczewski K.: Metallic Recuperators to Glass Tanks. Kosice, Technical University of Kosice, 1998, 283287, ISBN-80-7099-371-5

[3] Karczewski K.: Foundry and Metallurgy Engineering, 29 (2003) 2

[4] Karczewski K.: Obliczenia cieplne rekuperatorów metalowych dla pieców przemysłowych. UWND AGH, Kraków, 2004, SU 1667

[5] Redr M.: Vyużiti odpadniho tepla v hutnictvi żeleza. Praha, SNTL 1971

[6] Senkara T.: Obliczenia pieców grzewczych w hutnictwie żelaza. Śląsk, Katowice, 1968

[7] Catalog: Glass-Making Industry. ZM Ropczyce, 2004

[8] Catalog: Heat Exchangers. Motim - Hungary, 1992

Received

December 2005 